\title{
Assessment of Antigout, Antioxidant and Production Performance Augmenting Activity of Piper betle L. in Gout Induced Broiler Chicken
}

Vikrama Chakravarthi Periasamy, Murugesan Sundaravelayutham ${ }^{1}$, Arivuchelvan Arivalagan, Sukumar Karupannan, Arulmozhi Ayyasamy, Jagadeeswaran Appusamy

10.18805/IJAR.B-4250

\begin{abstract}
Background: The gout is commonly reported in birds and causes severe economic losses to the farmers. Hence to prevent the gout occurrence P.betle L. herb was selected and its antigout potential was studied in comparison with Allopurinol.

Methods: The biological experiment was conducted with 120 broiler chicks and was divided into 5 treatment groups of 8 birds each with triplicate study for six weeks. The groups were control $\left(\mathrm{T}_{1}\right)$, gout control $\left(\mathrm{T}_{2}\right)$, Allopurinol $\left(\mathrm{T}_{3}\right)$, P.betle $\mathrm{L}$. - $10 \mathrm{~g} / \mathrm{kg}\left(\mathrm{T}_{4}\right)$ and P.betle $\mathrm{L}$. $-12.5 \mathrm{~g} / \mathrm{kg}$ of feed $\left(\mathrm{T}_{5}\right)$. The gout was induced using toxic dose of sodium bicarbonate in water $(20 \mathrm{~g} /$ litre). The clinical signs and production performance were recorded and gross and histopathology studies were conducted. Serum biochemical parameters viz., uric acid and creatinine were periodically estimated (day 10,15, 18 and 42 of trial) and anti-oxidant and xanthine oxidase enzyme activity were measured.

Result: The production performances and the antioxidant activity were improved in P.betle L. groups and even better than Allopurinol. Also progressive reduction of uric acid and equivalent suppression of xanthine oxidase activity as that of Allopurinol were observed. Hence P.betle L. herb can be used effectively in the prevention of gout in birds.
\end{abstract}

Key words: Allopurinol, Broiler chicken, Gout, P.betle L., Xanthine oxidase.

\section{INTRODUCTION}

The gout is one of the major metabolic disorders in broiler chicken which causes heavy economic loss to the farming community of India (Prathapkumar et al. 2008). Allopurinol is a xanthine oxidase enzyme inhibitor used commonly for the prevention and treatment of gout by suppressing the production of uric acid. However, its use is limited due to the side effects like oxidative stress in broiler chicken and thereby reduction in the production performance of the bird (Carro et al. 2010). Hence an alternative to Allopurinol synthetic drug, the natural sources could be used to inhibit the xanthine oxidase enzyme (Kong et al. 2000). Among the natural sources, the herbs possessing the phytocompounds such as polyphenols and flavonoids were used as xanthine oxidase inhibitors (Chang et al. 1993). Also the alkaloids, essential oils and phenolic compounds of herbs showed the antigout activity through their xanthine oxidase inhibitory action (Ling and Bochu, 2014). Hence the present study was designed to explore the prophylactic antigout activity of $P$. betle L. medicinal herb and to find out the mechanism of antigout action in the broiler chicken.

\section{MATERIALS AND METHODS}

$P$. betle L. herb local variety (Karpoori) was collected from different regions of Namakkal District of South India, Tamil Nadu and authenticated by the Botanical Survey of India (No.BSI/SRI/5/23/2017/Tech/1921) Govt. of India, Coimbatore, Tamil Nadu. The freshly collected leaves of $P$.betle $L$. herb were shade dried for the preparation of herbal
Veterinary College and Research Institute, Tamil Nadu Veterinary and Animal Sciences University, Namakkal-637 001, Tamil Nadu, India. ${ }^{1}$ Veterinary College and Research Institute, Tamil Nadu Veterinary and Animal Sciences University, Theni-625 531, Tamil Nadu, India.

Corresponding Author: Vikrama Chakravarthi Periasamy, Veterinary College and Research Institute, Tamil Nadu Veterinary and Animal Sciences University, Namakkal-637 001, Tamil Nadu, India. Email: drvikramvet@gmail.com

How to cite this article: Periasamy, V.C., Sundaravelayutham, M., Arivalagan, A., Karupannan, S., Ayyasamy, A. and Appusamy, J. (2021). Assessment of Antigout, Antioxidant and Production Performance Augmenting Activity of Piper betle L. in Gout Induced Broiler Chicken. Indian Journal of Animal Research. DOI: 10.18805/ IJAR.B-4250.

Submitted: $14-07-2020$ Accepted: 12-01-2021 Online: 30-04-2021

extract and the dried leaves were finely powdered using a mechanical mixer and then collected in clean polythene bags.

The aqueous and alcoholic extracts were prepared separately using 100 grams of P.betle L. powder in $400 \mathrm{~mL}$ of distilled water and $400 \mathrm{~mL}$ of alcohol, respectively. Both extracts were kept in an orbital shaker for continuous agitation at 200 RPM for 72 hours. The extract was filtered through Whatman filter paper for three times after which a clear aqueous extract was obtained. The alcoholic extract was evaporated at $35^{\circ} \mathrm{C}$ under reduced pressure using rotary evaporator and then preserved for phytochemical analysis. 
Assessment of Antigout, Antioxidant and Production Performance Augmenting Activity of Piper betle L. in Gout Induced...

The qualitative phytochemical screening of aqueous and alcoholic extract of P.betle L. leaves crude powder was carried out using the method of Harborne (1973) at the laboratory of Ethno Veterinary Herbal Research Centre for Poultry, Namakkal, Tamil Nadu. The total alkaloids content (Harborne, 1973), total phenols (Singleton et al. 1999) and total flavonoids (Chang et al. 2002) content of $P$. betle L. were estimated using double beam UV-Visible spectrophotometer. Gas Chromatography-Mass Spectrometry (GC-MS) analysis was performed to identify the bioactive components present in the alcoholic extract of P. betle L. The analysis was performed in GC-MS 5975 C Agilent System and Turbo Mass software was adopted to handle mass spectra and chromatograms (Adams, 2007).

The experimental trail was conducted in the poultry farm belonging to department of Veterinary Pharmacology and Toxicology, Veterinary College and Research Institute, Namakkal during the month of June-July 2018. The effect of $P$. betle L. herb was studied at the dose rate of $10 \mathrm{~g} / \mathrm{kg}$ and $12.5 \mathrm{~g} / \mathrm{kg}$ of feed against gout induced broiler chicken. One hundred and twenty (120) day old broiler chicks were divided into five groups of eight birds each with triplicate experiment and they were maintained under standard environmental condition for six weeks. The groups were control $\left(T_{1}\right)$, gout control $\left(T_{2}\right)$, Allopurinol $\left(T_{3}\right)$, P. betle $L$. $-10 \mathrm{~g} / \mathrm{kg}\left(\mathrm{T}_{4}\right)$ and P.betle L. - $12.5 \mathrm{~g} / \mathrm{kg}$ of feed $\left(\mathrm{T}_{5}\right)$.

Gout was induced by sodium bicarbonate (Mubarak and Sharkay, 1999) dissolved in drinking water @ $20 \mathrm{~g} / \mathrm{L}$ from $11^{\text {th }}$ day to $14^{\text {th }}$ day (four days) of age in all groups, except control. The herbal dosing was commenced prophylactically on $3^{\text {rd }}$ day of age of broiler chicks and continued during the gout induction period and withdrawn on $20^{\text {th }}$ day, whereas Allopurinol dosing was commenced on $8^{\text {th }}$ day of age at the dose rate of $25 \mathrm{mg} / \mathrm{kg}$ body weight (Carro et al. 2010) and given for one week.

The clinical signs and mortality rate were noted and the production performance parameters like feed intake, body weight gain were recorded and the feed conversion ratio was calculated. The blood samples were collected before the gout induction ( $10^{\text {th }}$ day) and after the gout induction $\left(15^{\text {th }}, 18^{\text {th }}\right.$ and $21^{\text {st }}$ day) for serum uric acid and creatinine analysis. Likewise blood samples were also collected before slaughter on $42^{\text {nd }}$ day to estimate the kidney and liver function parameters (Aspartate aminotransferase (AST), Alanine aminotransferase (ALT) enzymes). All birds were slaughtered on $42^{\text {nd }}$ day and gross pathological changes were recorded and the organs showing lesions were collected in $10 \%$ neutral buffered formalin for histopathology studies (Bancroft and Gamble, 2008).

The liver samples were collected to study the antioxidant activity by estimating the superoxide dismutase (SOD) (Marklund and Marklund, 1974), catalase (CAT) (Claiborne, 1985 ) and total reduced glutathione (GSH) content (Ellmans, 1959) in double beam UV/ Visible spectrophotometer. Also liver tissues were frozen in liquid nitrogen for the estimation of xanthine oxidase activity (Settle et al. 2012). Experimental data was statistically analyzed in complete randomized design (Snedecor and Cochran, 2004)

\section{RESULTS AND DISCUSSION \\ Phytochemical analysis}

The results of qualitative phytochemical analysis of aqueous and alcoholic extracts of P.betle L. revealed the presence of alkaloids, carbohydrates, flavonoids, phenols, saponins and terpenoids. Further quantitative phytochemical analysis revealed the presence of alkaloids $(62.00 \pm 0.57 \mathrm{mg} / \mathrm{g})$, flavonoids (7.68 $\pm 0.36 \mathrm{mg}$ of Rutin/g) and phenols (130.00 $\pm 1.15 \mathrm{mg}$ of Gallic Acid Equivalent/g) which has antigout and antioxidant activity (Ling and Bochu, 2014). The phytocompounds detected in the GC-MS analysis are shown with their retention time (RT) and the area percentage (Table 1 and Fig 1). The major biologically active phytocompounds like acetoxy chavichol, chavibetol, eugenol, beta and gamma tocopherol, phytol and beta sitosterol were detected in the leaves of Piper betle L.

\section{Biological experiment}

A detailed biological experiment was conducted to study the antigout and antioxidant activity of P.betle L. herb in different doses $(10 \mathrm{~g} / \mathrm{kg}$ and $12.5 \mathrm{~g} / \mathrm{kg}$ feed) in comparison with a standard antigout drug namely allopurinol in gout induced broiler chicken.

\section{Production performance parameters estimation}

The results of production performance parameters (Table 2) showed the equivalent body weight with less feed intake of $P$. betle L. groups than control and better feed efficiency than Allopurinol. These findings might be due to the presence of antistress and antioxidant phytochemicals like ûavonoids, polyphenols, terpenoids and alkaloids in $P$. betle leaves (Awang, 1988). But the production performance was declined in the allopurinol treatment group which might be due to the oxidative stress (Carro et al. 2010). The influence of antioxidants on the body weight was very well correlated with the higher values of tissue SOD, CAT and GSH level in the $P$. betle leaves group. The presence of Vitamin $E$ in $P$. betle $\mathrm{L}$. herb might have reduced the stress due to gout induction in broiler chicken and prevented the predisposition to death and also improved the appetite and body weight in broiler chicken (Traber and Atkinson, 2007).

The gout syndrome is commonly occurs at the age of 10-14 days in broiler chicks (Prathapkumar et al. 2008) hence in the present study, the gout was induced on $10^{\text {th }}$ day of age using toxic dose of sodium bicarbonate. The clinical signs viz. watery droppings, dullness, depression and unthriftiness and subsequent mortality (four birds) occurred in gout control group only. The hyperuricimia and higher creatinine level in gout control group bird's causes gout leading to development of clinical signs (Sodhi et al. 2008). The clinical signs and mortality did not occur in control and all the treatment groups, till the end of the trial which showed the protective effect of Allopurinol and P. betle L. treatment groups in gout induced broiler chicken. 


\section{Biochemical parameters, Antioxidant and Xanthine oxidase estimation}

The progressive reduction of serum uric acid by the $P$. betle L. treatment groups from day 15 to day 42 (Table 3) showed the prevention activity of herb against the development of gout in broiler chicken. It is also authenticated by the reduced xanthine oxidase enzyme activity (Table 5), which one is major culprit for hyperuricemia. Since the xanthine oxidase
(XO) enzyme is a key mediator in uric acid production in liver and well known therapeutic target for many allopathic hypouricemic agents (Borges et al. 2002), the estimation of hepatic xanthine oxidase in the gout induced broiler chicken could be a vital parameter to explore the antigout activity. The equivalent suppression of xanthine oxidase enzyme activity showed by $P$. betle L. groups as that of allopurinol indicated the probable mechanism of antihyperuricemic

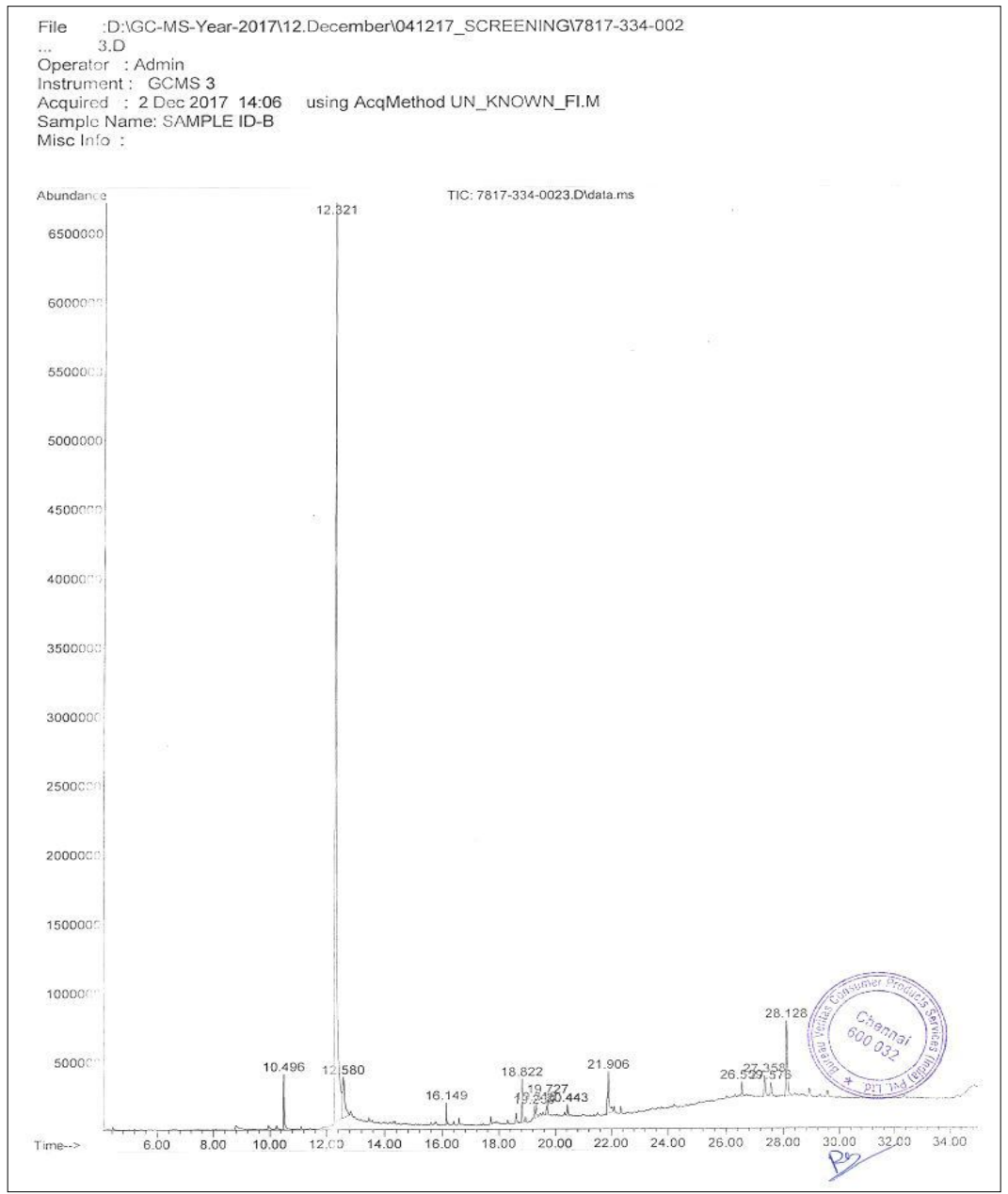

Fig 1: GC-MS chromatogram of $P$. betle L. alcoholic extract.

Table 1: Results of major phytoactive compounds detected in the GC-MS analysis of $P$. betle L. extract.

\begin{tabular}{|c|c|c|c|}
\hline S. No & Name of the component & Retention time value (Minutes) & Area \% \\
\hline 1 & $\begin{array}{l}\text { a. Chavibetol / } 3 \text { allyl } 6 \text { methoxy phenol } \\
\text { b. Eugenol }\end{array}$ & 10.497 & 2.70 \\
\hline 2 & a. Acetoxy chavichol / 4, allyl-1,2-diacetoxy benzene & 12.322 & 70.97 \\
\hline 3 & a. 4 Chromanol & 12.578 & 6.31 \\
\hline 4 & a. Phytol & 18.821 & 2.18 \\
\hline 5 & $\begin{array}{l}\text { a. Vitamin E, } \\
\text { b. Gamma tocopherol } \\
\text { c. O-methyl dl alpha tocopherol }\end{array}$ & 26.557 & 1.17 \\
\hline 6 & $\begin{array}{l}\text { a. Gamma sitosterol } \\
\text { b. Beta sitosterol }\end{array}$ & 28.126 & 6.20 \\
\hline
\end{tabular}


activity. The xanthine oxidase inhibitory activity might be due to presence of acetoxy chavichol (Tanaka et al. 1997) in $P$. betle $L$. which might have reduced the uric acid generation. The diuretic activity of phytol (Krishnamoorthy and Subramaniam, 2014) compound present in P. betle L. might have helped in the excretion of excess uric acid formed during gout induction.

Also, serum creatinine levels of $P$. betle L. did not differ with control group at any stage of experiment (Table 3 ). This finding revealed that the renal functions were not affected due to gout induction in the $P$. betle L. groups. Further, the results of serum biochemistry showed better total protein, albumin, globulin and albumin: globulin ratio level and reduced levels of ALT and AST (Table 4). Hence, the prophylactic dosing of herbs protected the visceral organs viz. kidney, liver and heart from the gout induced damage as evidenced by Behtari and Feizi (2015).
The antioxidant activity $P$. betle $\mathrm{L}$. is comparable with that of control group (Table 5). The values of SOD, CAT and GSH indicated the better antioxidant activity of P.betle L. groups than allopurinol. The occurrence of oxidative stress in allopurinol treatment group was evidenced by the declined values of SOD, CAT and GSH than control and P. betle L. groups (Carro et al. 2010). The presence of antioxidant phytochemicals like flavonoids, polyphenols, terpenoids and alkaloids in P. betle leaves (Awang, 1988) might have contributed the antioxidant activity when compared to allopurinol.

\section{Gross and histopathology findings}

pathological examination of gout control group birds showed severe chalky white deposits over heart and liver (Fig 2) and severe mottling of kidney with urate deposits and dilated ureter (Fig 3). Histopathology findings also revealed that

Table 2: Results of production performance parameters of treatment groups in gout induced broiler chicken at the end of the experiment $(\mathrm{n}=8)($ Mean $\pm \mathrm{SE})$.

\begin{tabular}{|c|c|c|c|c|c|}
\hline Parameter & $\begin{array}{c}\text { Control } \\
\left(T_{1}\right)\end{array}$ & $\begin{array}{c}\text { Gout Control } \\
\left(\mathrm{T}_{2}\right)\end{array}$ & $\begin{array}{c}\text { Allopurinol } \\
25 \mathrm{mg} / \mathrm{kg}\left(\mathrm{T}_{3}\right)\end{array}$ & $\begin{array}{c}\text { P. betle } \\
10 \mathrm{~g} / \mathrm{kg}\left(\mathrm{T}_{4}\right)\end{array}$ & $\begin{array}{c}P . \text { betle } \\
12.5 \mathrm{~g} / \mathrm{kg}\left(\mathrm{T}_{5}\right)\end{array}$ \\
\hline Body weight $(\mathrm{g})$ & $2188.67^{\mathrm{cd}} \pm 14.79$ & $1324.33^{\mathrm{a}} \pm 31.32$ & $2126.33^{b} \pm 14.99$ & $2154.17^{c} \pm 30.59$ & $2151.83^{c} \pm 14.74$ \\
\hline Feed intake (g) & $4030.00^{d} \pm 5.16$ & $2896.00^{\mathrm{a}} \pm 20.92$ & $4020.00^{\mathrm{d}} \pm 6.83$ & $3950.00^{b} \pm 5.16$ & $3945.00^{\mathrm{b}} \pm 5.16$ \\
\hline Feed Conversion ratio & $1.84^{b} \pm 0.01$ & $2.18=d \pm 0.05$ & $1.89^{c} \pm 0.01$ & $1.83^{a b} \pm 0.02$ & $1.83^{\mathrm{ab}} \pm 0.01$ \\
\hline
\end{tabular}

Columns bearing common superscript did not vary significantly at $5 \%(P<0.05)$ level.

Table 3: Results of serum uric acid $(\mathrm{mg} / \mathrm{dL})$ and creatinine $(\mathrm{mg} / \mathrm{dL})$ level of treatment groups in gout induced broiler chicken $(\mathrm{n}=8)$ $($ Mean $\pm \mathrm{SE})$.

\begin{tabular}{|c|c|c|c|c|c|c|}
\hline Age & Parameter & $\begin{array}{c}\text { Control } \\
\left(T_{1}\right)\end{array}$ & $\begin{array}{c}\text { Gout Control } \\
\qquad\left(\mathrm{T}_{2}\right)\end{array}$ & $\begin{array}{c}\text { Allopurinol } \\
25 \mathrm{mg} / \mathrm{kg}\left(\mathrm{T}_{3}\right)\end{array}$ & $\begin{array}{c}P . \text { betle } \\
10 \mathrm{~g} / \mathrm{kg}\left(\mathrm{T}_{4}\right)\end{array}$ & $\begin{array}{c}\text { P.betle } \\
12.5 \mathrm{~g} / \mathrm{kg}\left(\mathrm{T}_{5}\right)\end{array}$ \\
\hline \multirow[t]{2}{*}{ Day 10} & Uric acid & $9.81^{a} \pm 0.19$ & $9.61^{\mathrm{a}} \pm 1.00$ & $9.75^{\mathrm{a}} \pm 0.21$ & $9.77^{a} \pm 0.15$ & $9.66^{a} \pm 0.13$ \\
\hline & Creatinine & $0.47^{a} \pm 0.02$ & $0.45^{a} \pm 0.04$ & $0.48^{a} \pm 0.00$ & $0.47^{a} \pm 0.04$ & $0.46^{a} \pm 0.00$ \\
\hline \multirow[t]{2}{*}{ Day 15} & Uric acid & $9.61^{a} \pm 0.19$ & $28.21^{\mathrm{e}} \pm 1.00$ & $10.15^{a} \pm 0.21$ & $15.07^{c} \pm 0.15$ & $15.16^{c} \pm 0.13$ \\
\hline & Creatinine & $0.45^{a} \pm 0.19$ & $0.86^{b} \pm 0.07$ & $0.45^{\mathrm{a}} \pm 0.01$ & $0.46^{a} \pm 0.01$ & $0.47^{a} \pm 0.01$ \\
\hline \multirow[t]{2}{*}{ Day 18} & Uric acid & $9.21^{a} \pm 0.39$ & $25.05^{d} \pm 0.70$ & $9.30^{\mathrm{a}} \pm 0.24$ & $13.09^{b} \pm 0.51$ & $13.42^{b} \pm 0.63$ \\
\hline & Creatinine & $0.45^{a} \pm 0.02$ & $0.79^{b} \pm 0.00$ & $0.48^{a} \pm 0.01$ & $0.45^{\mathrm{a}} \pm 0.02$ & $0.47^{a} \pm 0.00$ \\
\hline \multirow[t]{2}{*}{ Day 21} & Uric acid & $9.37^{a} \pm 0.40$ & $24.02^{c} \pm 0.64$ & $9.54^{a} \pm 0.24$ & $9.60^{a} \pm 0.34$ & $9.64^{a} \pm 0.21$ \\
\hline & Creatinine & $0.44^{a} \pm 0.02$ & $0.74^{b} \pm 0.01$ & $0.43^{a} \pm 0.02$ & $0.44^{a} \pm 0.02$ & $0.45^{a} \pm 0.02$ \\
\hline \multirow[t]{2}{*}{ Day 42} & Uric acid & $6.61^{a} \pm 0.20$ & $21.97^{c} \pm 0.13$ & $6.51^{a} \pm 0.20$ & $6.61^{a} \pm 0.32$ & $6.65^{a} \pm 0.36$ \\
\hline & Creatinine & $0.42^{\mathrm{a}} \pm 0.02$ & $0.78^{\mathrm{b}} \pm 0.01$ & $0.43^{a} \pm 0.01$ & $0.44^{a} \pm 0.01$ & $0.43^{a} \pm 0.01$ \\
\hline
\end{tabular}

Columns bearing common superscript did not vary significantly at $5 \%(P<0.05)$ level.

Table 4: Results of serum total protein, albumin, globulin, albumin:globulin ratio, ALT and AST of treatment groups in gout induced broiler chicken at the end of the experiment $(n=8)($ Mean $\pm S E)$.

\begin{tabular}{lccccc}
\hline Parameter & $\begin{array}{c}\text { Control } \\
\left(\mathrm{T}_{1}\right)\end{array}$ & $\begin{array}{c}\text { Gout Control } \\
\left(\mathrm{T}_{2}\right)\end{array}$ & $\begin{array}{c}\text { Allopurinol } \\
25 \mathrm{mg} / \mathrm{kg}\left(\mathrm{T}_{3}\right)\end{array}$ & $\begin{array}{c}P . \text { betle } \\
10 \mathrm{~g} / \mathrm{kg}\left(\mathrm{T}_{4}\right)\end{array}$ & $\begin{array}{c}P . \text { betle } \\
12.5 \mathrm{~g} / \mathrm{kg}\left(\mathrm{T}_{5}\right)\end{array}$ \\
\hline Total Protein $(\mathrm{g} / \mathrm{dL})$ & $3.40^{\mathrm{a}} \pm 0.12$ & $4.02^{\mathrm{b}} \pm 0.04$ & $3.42^{\mathrm{a}} \pm 0.11$ & $3.36^{\mathrm{a}} \pm 0.08$ & $3.37^{\mathrm{a}} \pm 0.13$ \\
Albumin $(\mathrm{g} / \mathrm{dL})$ & $1.69^{\mathrm{a}} \pm 0.06$ & $2.51^{\mathrm{b}} \pm 0.05$ & $1.71^{\mathrm{a}} \pm 0.10$ & $1.63^{\mathrm{a}} \pm 0.08$ & $1.61^{\mathrm{a}} \pm 0.08$ \\
Globulin $(\mathrm{g} / \mathrm{dL})$ & $1.71^{\mathrm{b}} \pm 0.10$ & $1.50^{\mathrm{a}} \pm 0.03$ & $1.71^{\mathrm{b}} \pm 0.12$ & $1.73^{\mathrm{b}} \pm 0.08$ & $1.75^{\mathrm{b}} \pm 0.16$ \\
Albumin Globulin Ratio & $1.01^{\mathrm{a}} \pm 0.08$ & $1.66^{\mathrm{b}} \pm 0.05$ & $1.04^{\mathrm{a}} \pm 0.12$ & $0.96^{\mathrm{a}} \pm 0.08$ & $1.0^{\mathrm{a}} 2.0 \pm 0.16$ \\
ALT (U/L) & $26.08^{\mathrm{a}} \pm 1.33$ & $59.11^{\mathrm{b}} \pm 1.75$ & $29.47^{\mathrm{a}} \pm 2.01$ & $27.53^{\mathrm{a}} \pm 1.98$ & $27.32^{\mathrm{a}} \pm 0.43$ \\
AST (U/L) & $182.83^{\mathrm{a}} \pm 4.14$ & $342.35^{\mathrm{b}} \pm 8.82$ & $189.00^{\mathrm{a}} \pm 4.26$ & $182.28^{\mathrm{a}} \pm 5.50$ & $185.40^{\mathrm{a}} \pm 4.46$ \\
\hline
\end{tabular}

Columns bearing common superscript did not vary significantly at $5 \%(P<0.05)$ level. 
Table 5: Results of SOD, CAT, GSH and xanthine oxidase enzyme activity of treatment groups in gout induced broiler chicken at the end of the experiment $(n=8)$ (Mean $\pm S E)$.

\begin{tabular}{lccccc}
\hline Parameter & $\begin{array}{c}\text { Control } \\
\left(\mathrm{T}_{1}\right)\end{array}$ & $\begin{array}{c}\text { Gout Control } \\
\left(\mathrm{T}_{2}\right)\end{array}$ & $\begin{array}{c}\text { Allopurinol } \\
25 \mathrm{mg} / \mathrm{kg}\left(\mathrm{T}_{3}\right)\end{array}$ & $\begin{array}{c}P . \text { betle } \\
10 \mathrm{~g} / \mathrm{kg}\left(\mathrm{T}_{4}\right)\end{array}$ & $\begin{array}{c}P . \text { betle } \\
12.5 \mathrm{~g} / \mathrm{kg}\left(\mathrm{T}_{5}\right)\end{array}$ \\
\hline SOD(Units/ mg protein) & $1.15^{\mathrm{c}} \pm 0.01$ & $0.78^{\mathrm{a}} \pm 0.01$ & $0.98^{\mathrm{b}} \pm 0.01$ & $1.14^{\mathrm{c}} \pm 0.01$ & $1.14^{\mathrm{c}} \pm 0.02$ \\
CAT(Units/ mg protein) & $9.27^{\mathrm{c}} \pm 0.21$ & $6.37^{\mathrm{a}} \pm 0.22$ & $8.58^{\mathrm{b}} \pm 0.26$ & $9.33^{\mathrm{c}} \pm 0.15$ & $9.39^{\mathrm{c}} \pm 0.17$ \\
GSH(Units/ mg protein) & $10.60^{\mathrm{c}} \pm 0.10$ & $8.04^{\mathrm{a}} \pm 0.01$ & $9.96^{\mathrm{b}} \pm 0.03$ & $10.38^{\mathrm{c}} \pm 0.11$ & $10.38^{\mathrm{c} \pm 0.04}$ \\
XO activity(Units/ mg protein) & $7.85^{\mathrm{abc}} \pm 0.04$ & $8.70^{\mathrm{d}} \pm 0.05$ & $7.72^{\mathrm{a}} \pm 0.04$ & $7.75^{\mathrm{ab}} \pm 0.04$ & $7.75^{\mathrm{ab} \pm 0.06}$ \\
\hline
\end{tabular}

Columns bearing common superscript did not vary significantly at $5 \%(P<0.05)$ level.

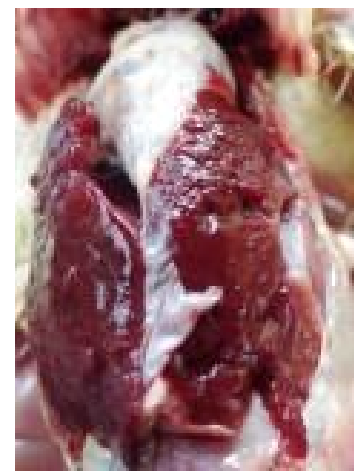

Fig 2: Gout control group $\left(\mathrm{T}_{2}\right)$ day 14 - severe chalky white urate deposits over heart and in liver leads to loss of hepatic architecture.

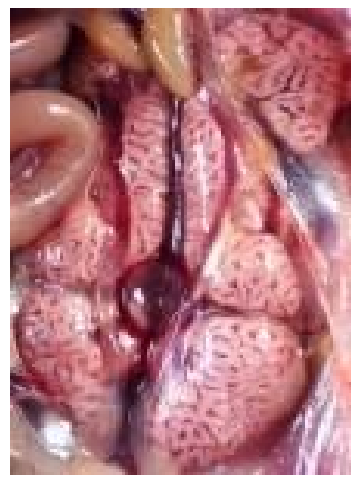

Fig 3: Gout control group $\left(T_{2}\right)$ day 14 - severe mottling of kidney with urate deposits and dilated ureter.

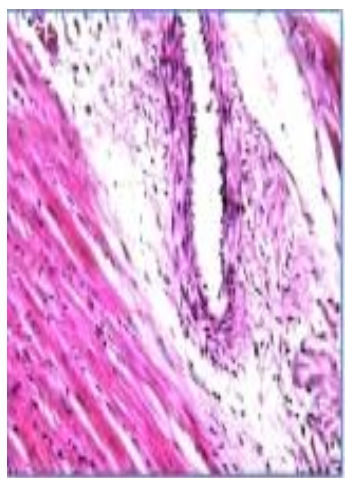

Fig 4: Gout control group $\left(\mathrm{T}_{2}\right)$ day 14-heart showing disrupted myofibers and fibrous tissue hyperplasia.

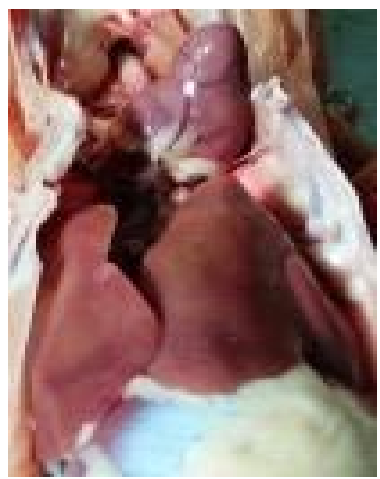

Fig 6: $P$. betle L. $-10 \mathrm{~g} / \mathrm{kg}\left(\mathrm{T}_{4}\right)$ day 42 -normal heart and liver due to herb supplementation.

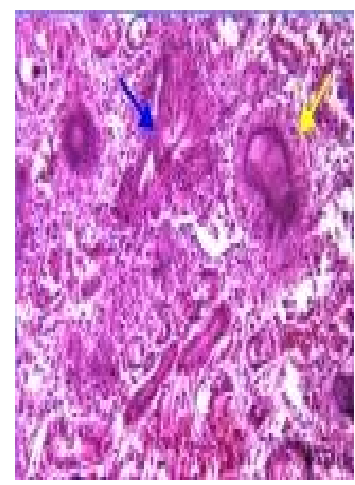

Fig 5: Gout control group $\left(T_{2}\right)$ day 14 - kidney showing solidary (yellow arrow) and feathery pattern (blue arrow) of urate crystals and tubular necrosis.

the severe disruption of cardiac myofibers along with fibrous tissue hyperplasia in heart (Fig 4) and solid and feathery pattern of urate crystals and necrosis of tubular epithelium in renal tubules (Fig 5) in gout control group. Whereas the Allopurinol and P.betle L. $10 \mathrm{~g} / \mathrm{kg}$ (Fig 6 and 7) and P.betle L. $12.5 \mathrm{~g} / \mathrm{kg}$ group did not show any appreciable gross lesions and maintenance of normal architecture of visceral organs (heart, liver and kidney) in histopathology studies. The gross and histopathology pictures clearly illustrated that the prophylactic dosing of herbs prevented the gout induced damage in visceral organs and the effect is equivalent to allopurinol. The anti-inflammatory property of acetoxy chavichol, gamma and beta sitosterol (Saeidnia et al. 2014) and eugenol (Lee et al. 2007) of P.betle L. might have alleviated the gouty inflammation in broiler chicken. These 


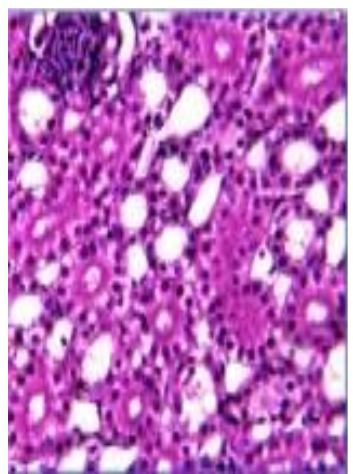

Fig 7: P. betle L. - $10 \mathrm{~g} / \mathrm{kg}\left(\mathrm{T}_{4}\right)$ day 42 - kidney revealing normal tubular and glomerular pattern due to herb supplementation.

findings are also very well supported by the earlier authors (Wang et al. 2016).

The results of present study showed that significant differences were not observed between $P$. betle $L$. treatment groups. Hence the most effective dose of $P$. betle L. viz. $10 \mathrm{~g} / \mathrm{kg}$ feed could be preferred as an economic point of view than $12.5 \mathrm{~g} / \mathrm{kg}$ group for prophylactic use.

\section{CONCLUSION}

The antigout activity of P.betle L. was due to the xanthine oxidase enzyme inhibitory activity as evidenced by the present study. The significant antioxidant activity exhibited by P.betle $L$. herb in gout induced chicken was also reflected in the production performance than Allopurinol treated group. The antigout, antioxidant and production performance augmenting activities of P.betle L. herb might be due to presence of pharmacologically active phytocompounds like acetoxy chavichol, eugenol, beta and gamma tocopherol, phytol and beta sitosterol which were detected in GCMS analysis.

Since there were no significant differences between the two different prophylactic dose level viz. $10 \mathrm{~g} / \mathrm{kg}$ and 12.5 $\mathrm{g} / \mathrm{kg}$ of feed, P.betle L. $10 \mathrm{~g} / \mathrm{kg}$ feed dose can be used efficiently as an alternative medicine to Allopurinol for the prevention of gout syndrome in broiler chicken.

\section{REFERENCES}

Adams, R.P. (2007). Identification of essential oil components by Gas Chromatography/Mass Spectrometry. $4^{\text {th }}$ Edition. Allured Publishing Corporation, Illinois, USA.

Awang, M.N. (1988). Betel quid and oral carcinogenesis. Singapore Medical Journal. 29: 589-593.

Bancroft, J.D. and Gamble, M. (2008). Theory and Practice of Histological Techniques, $6^{\text {th }}$ Edition, Churchill Livingstone, Elsevier, China.

Behtari, M. and Feizi, A. (2015). Investigation of production performance and measurement of some serum biochemical parameters in broiler breeder farm with gout syndrome. International Journal of Biology, Pharmacy and Allied Sciences. 4(2): 728-738.

Borges, F., Fernandes, E. and Roleira, F. (2002). Progress towards the discovery of xanthine oxidase inhibitors. Current Medicinal Chemistry. 9: 195-217.
Carro, M.D., Falkenstein, E., Radke, W.J. and Klandorf, H. (2010). Effects of allopurinol on uric acid concentrations, xanthine oxidoreductase activity and oxidative stress in broiler chickens. Comparative Biochemistry Physiology. 151: 12-17.

Chang, W.S., Lee, Y.J., Lu, F.J. and Chiang, H.C. (1993). Inhibitory effects of flavonoids on xanthine oxidase. Anticancer Research. 13: 2165-2170.

Chang, C.C., Yang, M.H., Wen, H.M. and Chern, J.C. (2002). Estimation of total flavonoid content in Propolis by two complementary colorimetric methods. Journal of Food and Drug Analysis. 10(3): 178-182.

Claiborne, A. (1985). Catalase Activity. In: CRC Handbook of Methods for Oxygen Radical Research. [R.A. Greenwald, (Ed.)]. Boca Raton, FL: CRC Press, Florida, USA, 1: 283-284.

Ellman, G.L. (1959). Tissue sulphydryl groups. Archives of Biochemistry and Biophysics. 82: 70-77.

Harborne, J.B. (1973). Phytochemical methods: a guide to modern techniques of plant analysis. Chapman and Hall, London, 84.

Kong, L.D., Zhang, Y., Pan, X., Tan, R.X. and Cheng, C.H.K. (2000). Inhibition of xanthine oxidase by liquiritigenin and isoliquiritigenin isolated from Sinofranchetia chinensis. Cellular and Molecular Life Sciences. 57(3): 500-505.

Krishnamoorthy, K. and Subramaniam, P. (2014). Phytochemical profiling of leaf, stem and tuber parts of Solena amplexicaulis (Lam.) using GC-MS. International Scholarly Research Notices. 1: 1-13.

Kumari, S and Rao, N.B. (2014). Phytochemical analysis of Piper betle leaf extract. World Journal of Pharmacy and Pharmaceutical Sciences. 4(1): 699-703.

Lee, Y.Y., Hung, S.L., Pai, S.F., Lee, Y.H. and Yang, S.F. (2007). Eugenol suppressed the expression of lipopolysaccharide induced proinflammatory mediators in human macrophages. Journal of Endodontics. 33: 698-702.

Ling, X. and Bochu, W. (2014). A review of phytotherapy of gout: perspective of new pharmacological treatments. Pharmazie. 69: 243-256.

Marklund, S. and Marklund, G. (1974). Involvement of the superoxide anion radical in the autooxidation of pyrogallol and a convenient assay for superoxide dismutase. European Journal of Biochemistry. 47(3): 469-474.

Mubarak, M. and Sharkawy, A.A. (1999). Toxicopathology of gout induced in laying pullets by sodium bicarbonate toxicity. Environmental Toxicology and Pharmacology. 7: 227-236.

Prathapkumar, S.M., Satyanarayana, M.L., Mallikarjuna, A.R. and Shivakumar, R. (2008). Serum biochemistry and epidemiology of gout in broiler chick. Indian Veterinary Journal. 85(4): 452-453.

Saeidnia, S., Manayi, A. Gohari, A. and Mohammad, A. (2014). The Story of Beta-sitosterol- A Review. European Journal of Medicinal Plants. 4(5): 590-609

Sarvaiya, V.N., Sadariya, K.A., Pancha, P.G., Thaker, A.M., Patel, A.C. and Prajapati, A.S. (2015). Evaluation of antigout activity of Phyllanthus emblica fruit extracts on potassium oxonate induced gout rat model. Veterinary World. 8(10): 1230-1236.

Settle, T., Carro, M.D., Falkenstein, E., Radke, W. and Klandorf, H. (2012). The effects of allopurinol, uric acid and inosine administration on xanthine oxidoreductase activity and uric acid concentrations in broilers. Poultry Science. 91: 2895-2903. 
Singleton, V.L., Orthofer, R., Rosa, M. and Raventos, L. (1999). Analysis of total phenols and other oxidation substrates and antioxidants by means of Folin Ciocalteu reagent. Methods in Enzymology. 299: 152-178.

Snedecor, G.W. and Cochran, W.G. (2004). Statistical Methods. $8^{\text {th }}$ ed., lowa State University / Ames, lowa - 50010.

Sodhi, S., Brar, R.S., Banga, H.S. and Nagra, S.S. (2008). Pathobiochemical studies on experimentally induced gout by administration of sodium bicarbonate in broilers. Toxicology International. 15: 117-120.

Traber, M.G. and Atkinson, J. (2007). Vitamin E, antioxidant and nothing more. Free Radical Biology and Medicine. 43(1): 4-15.
Tanaka, T., Makita, H., Kawamori, T., Kawabata, K., Mori, H., Murakami, A., Satoh, K. Hara, A., Ohigashi, H. and Koshimizu, K.A. (1997). Xanthine oxidase inhibitor acetoxychavicol acetate inhibits azoxymethane induced colonic aberrant crypt foci in rats. Carcinogenesis. 18(5): $1113-1118$.

Wang, X., Zhou, J., Shi, B., Guo, X. and Yan, Q. (2016). Hypouricemic and nephroprotective effects of Jianpi Huashi decoction in a rat model of hyperuricemia. International Journal of Clinical and Experimental Medicine. 9(1): 455-465. 